\title{
Article
}

\section{Casein Kinase 1D Encodes a Novel Drug Target in Hedgehog-GLI-Driven Cancers and Tumor-Initiating Cells Resistant to SMO Inhibition}

\author{
Elisabeth Peer ${ }^{1}$, Sophie Karoline Aichberger ${ }^{1}$, Filip Vilotic ${ }^{1}$, Wolfgang Gruber ${ }^{1,+}{ }^{\dagger}$, Thomas Parigger ${ }^{1,2}$, \\ Sandra Grund-Gröschke ${ }^{1, \ddagger}$, Dominik Patrick Elmer ${ }^{1}{ }^{(\mathbb{D}}$, Florian Rathje ${ }^{1}$, Andrea Ramspacher ${ }^{1,3}{ }^{\mathbb{D}}$, Mirko Zaja ${ }^{4}$, \\ Susanne Michel ${ }^{4}$, Svetlana Hamm ${ }^{4}$ and Fritz Aberger ${ }^{1, *(D)}$
}

1 Department of Bioscience, Cancer Cluster Salzburg, Paris-Lodron University Salzburg, 5020 Salzburg, Austria; elisabeth.peer@sbg.ac.at (E.P.); sophiekaroline.aichberger@sbg.ac.at (S.K.A.); viloticfi@web.de (F.V.); gruber.wolfi@gmail.com (W.G.); t.parigger@salk.at (T.P.); sandra.grund-groeschke@sbg.ac.at (S.G.-G.); dominikpatrick.elmer@sbg.ac.at (D.P.E.); florian.rathje@sbg.ac.at (F.R.); a.ramspacher@salk.at (A.R.)

2 Laboratory for Immunological and Molecular Cancer Research (SCRI-LIMCR), Salzburg Cancer Research Institute, Cancer Cluster Salzburg, IIIrd Medical Department, Paracelsus Medical University Salzburg, 5020 Salzburg, Austria

3 Research Program for Receptor Biochemistry and Tumor Metabolism, Department of Pediatrics, University Hospital of the Paracelsus Medical University, 5020 Salzburg, Austria

check for updates

Citation: Peer, E.; Aichberger, S.K.; Vilotic, F.; Gruber, W.; Parigger, T.; Grund-Gröschke, S.; Elmer, D.P.; Rathje, F.; Ramspacher, A.; Zaja, M.; et al. Casein Kinase 1D Encodes a Novel Drug Target in HedgehogGLI-Driven Cancers and Tumor-Initiating Cells Resistant to SMO Inhibition. Cancers 2021, 13, 4227. https://doi.org/10.3390/ cancers 13164227

Academic Editors: Cinzia Allegrucci and Paloma Ordóñez-Morán

Received: 17 June 2021

Accepted: 18 August 2021

Published: 23 August 2021

Publisher's Note: MDPI stays neutral with regard to jurisdictional claims in published maps and institutional affiliations.

Copyright: () 2021 by the authors. Licensee MDPI, Basel, Switzerland. This article is an open access article distributed under the terms and conditions of the Creative Commons Attribution (CC BY) license (https:// creativecommons.org/licenses/by/ $4.0 /)$.
4 4SC AG, Planegg-Martinsried, 82152 Planegg, Germany; Mirko.Zaja@4sc.com (M.Z.); Susanne.Michel@4sc.com (S.M.); svetlana.hamm@4sc.com (S.H.)

* Correspondence: fritz.aberger@plus.ac.at; Tel.: +43-662-8044-5792

$\dagger$ Present address: EVER Pharma GmbH, 4866 Unterach, Austria.

$\ddagger$ Present address: Immatics Biotechnologies GmbH, 72076 Tübingen, Germany.

Simple Summary: Uncontrolled activation of hedgehog $(\mathrm{HH})$ - GLI signaling contributes to the development of several human malignancies. Targeted inhibition of the HH-GLI signaling cascade with small-molecule inhibitors can reduce cancer growth, but patient relapse is very common due to the development of drug resistance. Therefore, a high unmet medical need exists for new drug targets and inhibitors to achieve efficient and durable responses. In the current study, we identified CSNK1D as a novel drug target in the HH-GLI signaling pathway. Genetic and pharmacological inhibition of CSNK1D activity leads to suppression of oncogenic HH-GLI signaling, even in cancer cells in which already approved $\mathrm{HH}$ inhibitors are no longer effective due to resistance mechanisms. Inhibition of CSNK1D function reduces the malignant properties of so-called tumor-initiating cells, thereby limiting cancer growth and presumably metastasis. The results of this study form the basis for the development of efficient CSNK1D inhibitors for the therapy of HH-GLI-associated cancers.

Abstract: (1) Background: Aberrant activation of the hedgehog ( $\mathrm{HH}$ - GLI pathway in stem-like tumor-initiating cells (TIC) is a frequent oncogenic driver signal in various human malignancies. Remarkable efficacy of anti-HH therapeutics led to the approval of $\mathrm{HH}$ inhibitors targeting the key pathway effector smoothened (SMO) in basal cell carcinoma and acute myeloid leukemia. However, frequent development of drug resistance and severe adverse effects of SMO inhibitors pose major challenges that require alternative treatment strategies targeting $\mathrm{HH}-\mathrm{GLI}$ in TIC downstream of SMO. We therefore investigated members of the casein kinase 1 (CSNK1) family as novel drug targets in HH-GLI-driven malignancies. (2) Methods: We genetically and pharmacologically inhibited CSNK1D in HH-dependent cancer cells displaying either sensitivity or resistance to SMO inhibitors. To address the role of CSNK1D in oncogenic HH signaling and tumor growth and initiation, we quantitatively analyzed $\mathrm{HH}$ target gene expression, performed genetic and chemical perturbations of CSNK1D activity, and monitored the oncogenic transformation of TIC in vitro and in vivo using 3D clonogenic tumor spheroid assays and xenograft models. (3) Results: We show that CSNK1D plays a critical role in controlling oncogenic GLI activity downstream of SMO. We provide evidence that inhibition of CSNK1D interferes with oncogenic HH signaling in both SMO inhibitor-sensitive and -resistant tumor settings. Furthermore, genetic and pharmacologic perturbation of CSNK1D decreases 
the clonogenic growth of GLI-dependent TIC in vitro and in vivo. (4) Conclusions: Pharmacologic targeting of CSNK1D represents a novel therapeutic approach for the treatment of both SMO inhibitorsensitive and -resistant tumors.

Keywords: Hedgehog_GLI signaling; Hedgehog pathway inhibitors; casein kinase 1D; smoothened drug resistance; tumor-initiating cells; cancer stem cells

\section{Introduction}

Cancer tissues typically display a hierarchical organization reflected by the existence of rare yet highly malignant stem-like tumor-initiating cells (TIC) and more abundant differentiated progeny. TICs are key to cancer initiation and growth, display less sensitivity to chemotherapeutics, and are endowed with self-renewal and metastatic capacity. They are frequently enriched in advanced, aggressive, and/or resistant tumors, and cells isolated from distant metastases often show a TIC phenotype [1,2]. A better understanding of the key molecular drivers and pathways accounting for the malignant properties of TICs is, therefore, of high therapeutic relevance.

On a molecular level, the hedgehog (HH) - GLI signaling pathway has been crucially implicated in the regulation of self-renewal, disseminating, and tumor-initiating capacity of TICs [3-7]. This pivotal role of HH-GLI in TICs makes targeted pharmacological inhibition of $\mathrm{HH}-\mathrm{GLI}$ signaling a promising therapeutic strategy to combat some of the major challenges in oncology such as patients' relapse and metastases formation.

The HH signaling pathway is of central importance during embryonic development and regeneration, where it controls a multitude of biological processes such as cell proliferation, differentiation, survival, cell metabolism, and stem cell fate. In line with its various key roles, aberrant activity of the pathway in humans is causally linked with several developmental syndromes and malignancies [8-11]. Canonical HH signaling starts with binding of the $\mathrm{HH}$ ligand protein to its receptor, Patched1 (PTCH1), a twelve-transmembrane domain protein which represses $\mathrm{HH}$ signaling in its unliganded state by inhibiting the transport of the G-protein-coupled receptor-like transmembrane protein, Smoothened (SMO), into the primary cilium [12]. In its activated state, SMO promotes the formation of active glioma-associated oncogene homolog (GLI) transcription factors by releasing GLI2/3 from their repressor, suppressor of fused (SUFU), thereby preventing proteolytic processing of GLI2/3. The unprocessed, full-length GLI proteins are then able to activate the expression of $\mathrm{HH}$ target genes, which promote tumor formation by inducing proliferation, anti-apoptotic signals, metastasis, cancer stem cell (CSC) self-renewal as well as expression of GLI1, leading to a strong positive feedback circuit. Furthermore, GLI1 expression serves as a reliable readout for HH-GLI pathway activation (for reviews, see [13-17]).

The first inhibitors of oncogenic HH-GLI that were approved by the FDA for the treatment of advanced and metastatic basal cell carcinoma (BCC) were the small molecule SMO inhibitors (SMOi), vismodegib and sonidegib [18-22]. More recently, the third SMOi glasdegib has been approved for the treatment of acute myeloid leukemia in combination with low-dose cytarabine [23]. Although the SMO inhibitors demonstrate remarkable therapeutic efficacy, they are also associated with severe side effects, such as muscle cramps, weight and hair loss, and taste disturbance. These adverse effects very frequently force discontinuation of the treatment [24]. However, drug withdrawal is often followed by tumor relapse, due to the existence of resistant tumors cells. Here, it is noteworthy that SMO inhibitors alone rarely eliminate all tumor cells, which allows residual tumor cells to persist and regrow [24]. A substantial proportion of BCC patients showing SMOi resistance express mutant SMO variants. Such mutations in SMO occur either directly in the SMO inhibitor-binding pocket or outside of the binding pocket in pivotal regions of the transmembrane-helices, abolishing or attenuating the antagonistic activity of SMOi drugs. Additionally, resistance to SMO inhibitors can be caused by GLI2 amplification 
or genetic loss of the GLI repressor SUFU [25-29]. Further, the antagonistic activity of SMO inhibitors can be bypassed by shifts towards phosphatidylinositol-3 kinase (PI3K) signaling, activation of mitogen activated protein kinase (MAPK) signaling, or by induction of atypical protein kinase $\mathrm{C}(\mathrm{aPKC})$ activity, the latter of which enhances transcriptional GLI activity independent of SMO function [28,30-33]. Along the same line, Whitson et al. demonstrated that serum response factor (SRF) and the coactivator megakaryoblastic leukemia 1 (MLK1) together with GLI1 activation drives non-canonical Hedgehog signaling and induces SMOi resistance in BCC patients [31].

Considering the numerous kinases and signaling pathways, also including EGF-MEKERK, FGF, PDGF, TGF, WNT, JAK/STAT, or DYRK [34-43] that interact with the HH signaling pathway and are often integrated and translated into synergistically regulated output signals via the GLI transcription factors, we focused on members of the casein kinase family with the goal of identifying novel druggable target proteins to inhibit oncogenic GLI function in this study. Members of the CSNK family have been shown to play multiple and diverse roles in $\mathrm{HH}$ signaling [44]. For instance, casein kinase 1 alpha (CSNK1A1) negatively regulates insect and vertebrate $\mathrm{HH}$ signaling by phosphorylating GLI3, and thereby inducing proteolytic processing of GLI3 full-length protein into C-terminally truncated repressor forms $[45,46]$. By contrast, CSNK1A1 has also been shown to phosphorylate SMO and thereby contribute to activation of HH signaling [47]. Similarly, CSNK2 activity has been identified as a driver signal and therapeutic target in $\mathrm{HH}$-dependent medulloblastoma [48]. Further evidence for an activating role of CSNK proteins came from studies in Drosophila showing that fly homologues of CSNK1 can phosphorylate and thereby stabilize the GLI homologue cubitus interruptus (Ci), increasing the transcriptional output of hh signaling in insects $[49,50]$. Together, these data suggest that pharmacologic inhibition of selected CSNK family members may be a promising therapeutic approach for $\mathrm{HH}-\mathrm{GLI}$-driven cancers, particularly malignancies with SMOi resistance.

Here, we identify casein kinase 1 delta (CSNK1D) as positive regulator of oncogenic GLI function and show that pharmacological as well as genetic targeting of CSNK1D is sufficient to abrogate $\mathrm{HH}$ - GLI signaling in both SMOi-sensitive and SMOi-resistant cancer cells driven by oncogenic GLI. Furthermore, we demonstrate a requirement of CSNK1D for GLI-dependent TIC properties in vitro and in vivo, and introduce a novel CSNK1D inhibitor with therapeutic activity against GLI-driven cancer cells.

\section{Results}

2.1. Genetic Perturbation of CSNK1D Interferes with Canonical, Oncogenic HH-GLI Signaling in Medulloblastoma Cells

To analyze whether CSNK1D is involved in the regulation of oncogenic HH signaling, we performed an shRNA-mediated knockdown of CSNK1D in a HH responsive human medulloblastoma cell line (Daoy). In Daoy cells, canonical HH signaling can be activated and inhibited by treatment with a small molecule, Smoothened agonist (SAG), and SMO antagonists, respectively [51,52] (Figure 1A). The GLI1 protein as well as mRNA levels of the HH target genes GLI1 and HHIP, whose expression significantly increases upon the addition of SAG, were used as readout parameter for $\mathrm{HH}$ pathway activity. In addition, Daoy cells express high levels of CSNK1D, which can be inhibited via shRNA-mediated knockdown (Figure 1B). Of note, knockdown of CSNK1D was sufficient to reduce HH target gene and GLI1 protein expression in Daoy medulloblastoma cells, suggesting that CSNK1D is required for canonical $\mathrm{HH}$ signaling and $\mathrm{HH}$ target gene activation (Figure 1B,C). Knockdown of CSNK1D showed no effect on primary cilia, suggesting that loss of CSNK1D directly interferes with GLI activation rather than via interfering with the formation of primary cilia, which serve as essential organelles in the reception and transduction of $\mathrm{HH}$ signaling upstream of GLI proteins (Figure S1A,B) [53]. 
A

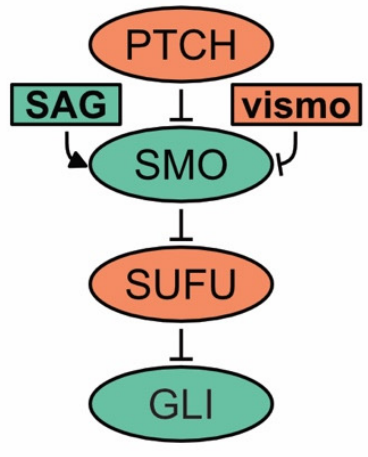

C

GLI1

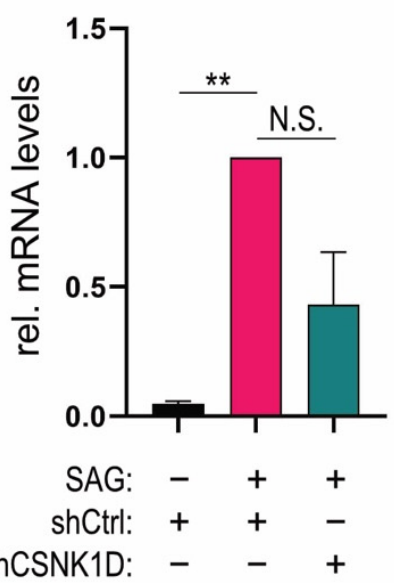

B

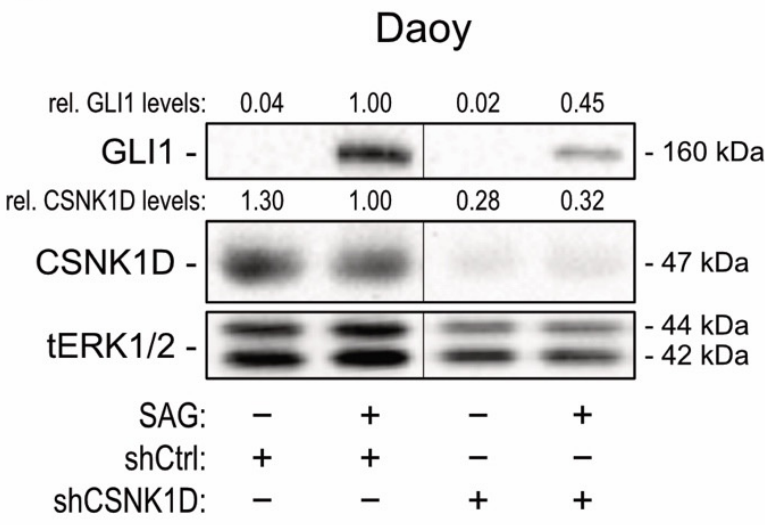

Daoy

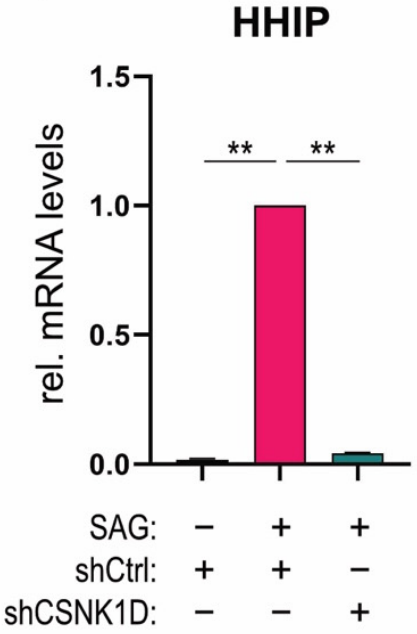

Figure 1. RNAi-mediated inhibition of CSNK1D interferes with canonical oncogenic HH-GLI signaling. (A) Simplified schematic illustration of the canonical HH-GLI signaling pathway with pathway activators in green and inhibitors in red. PTCH and SUFU inactivate the pathway, while it is turned on by the central pathway activator SMO causing activation of the GLI transcription factor. Pharmacologically, the SMO agonist SAG activates the pathway, while it is inhibited by the SMO inhibitor vismodegib. (B) Representative Western blot analysis of GLI1 and CSNK1D in Daoy medulloblastoma cells. Cells were lentivirally transduced with shCSNK1D or control shRNA (shCtrl) and treated with or without SAG [100 nM]. Relative quantification of Western blot bands was conducted via densitometric image analysis using Image Lab 5.0 software (Bio-Rad, Vienna, Austria). Relative protein levels normalized to the loading control tERK and to the shCtrl + SAG sample are shown above each protein band. (C) qPCR analysis of GLI1 and HHIP mRNA levels of Daoy cells treated as described in $(\mathbf{B})(n=3)$. Student's $t$ test was used for statistical analysis $\left.{ }^{* *} p<0.01\right)$.

\subsection{Genetic Inhibition of CSNK1D Reduces HH-GLI Activity in SMOi-Resistant Tumor Entities Driven by Oncogenic GLI}

To expand our investigations towards SMOi-resistant cancer cells, we turned to Ewing sarcoma (EWS) cells, where SMO-independent GLI1 expression is driven by the EWS-FLI1 fusion oncogene [54] (Figure 2A). Further, in EWS cells, GLI1 acts downstream of EWS-FLI1 as oncogene to promote proliferation and 3D spheroid growth [55]. In line with SMOi resistance of the GLI1-expressing EWS cell lines A673 and MHH-ES-1, only treatment with the GLI inhibitor HPI-1 led to reduced GLI1 protein levels, while treatment with the FDA-approved SMOi vismodegib (vismo) did not affect GLI1 expression (Figure 2B and Figure S2A) [56,57]. 
A
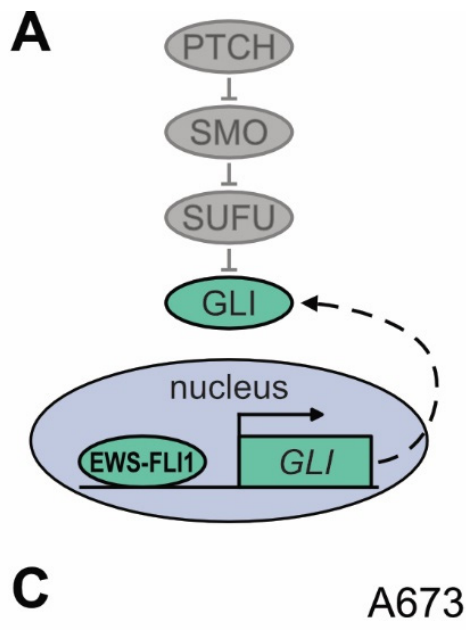

B

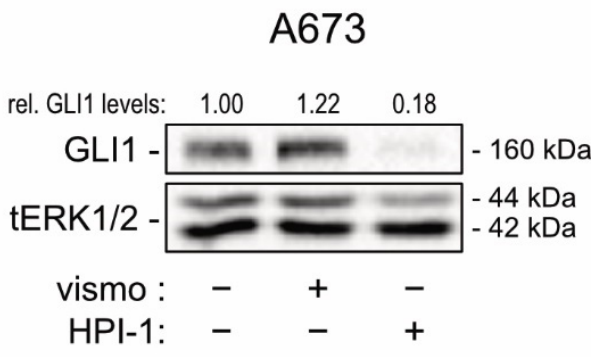

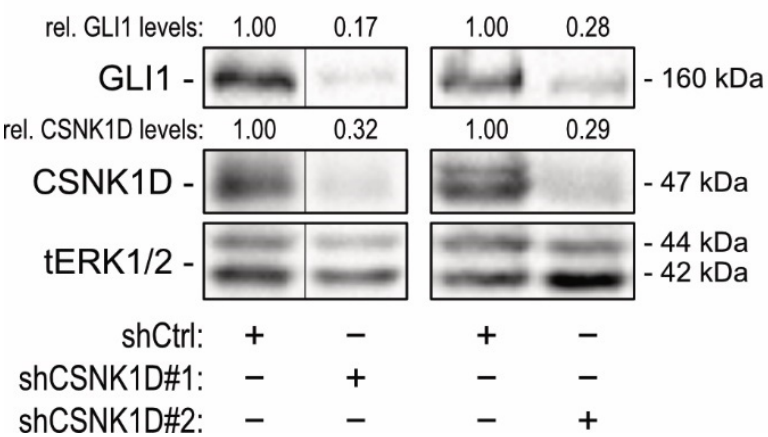

Figure 2. RNAi-mediated inhibition of CSNK1D interferes with oncogenic HH-GLI signaling in SMOi resistant Ewing sarcoma cells. (A) Simplified schematic illustration of non-canonical, SMOindependent HH-GLI signaling in Ewing sarcoma with EWS-FLI1-driven transcription of GLI1. (B) Representative Western blot analysis of GLI1 in A673 cells treated with vismodegib [1 $\mu \mathrm{M}]$ or HPI-1 [20 $\mu \mathrm{M}]$. (C) Representative Western blot analysis of GLI1 in A673 cells lentivirally transduced with shCSNK1D (\#1, \#2) or control shRNA (shCtrl). Relative quantification of Western blot bands was conducted via densitometric image analysis using Image Lab 5.0 software (Bio-Rad, Vienna, Austria). Relative protein levels normalized to the loading control tERK and to the Ctrl sample are shown above each protein band.

To investigate whether CSNK1D regulates GLI activity also in SMO-independent cells, we performed shRNA-mediated knockdown of CSNK1D in A673 cells. As shown in Figure 2C and Figure S2B, genetic perturbation of CSNK1D reduced GLI1 protein levels, suggesting that CSNK1D also regulates SMO-independent GLI activity. To support these results, we inactivated CSNK1D by CRISPR-Cas9 in the EWS cell line MHH-ES-1 and confirmed that deletion of CSNK1D results in reduced GLI1 protein levels (Figure S2C).

\subsection{Pharmacological Targeting of CSNK1D Inhibits HH-GLI Signaling in Both Canonical and Non-Canonical Settings}

The critical role of CSNK1D in SMO-dependent and SMO-independent GLI activation prompted us to analyze the possible therapeutic effect of CSNK1D inhibitors by targeting oncogenic GLI transcription factors. In a collaborative approach, we performed a compound screen cascade in A549 non-small cell lung carcinoma (NSCLC) cells under proliferating and non-proliferating conditions to select for compounds interfering with quiescent and TIC properties. This approach identified a novel, highly effective CSNK1D inhibitor, termed CK1D008 (Figure S3A). To investigate whether chemical perturbation of CSNK1D can interfere with HH-GLI signaling, we treated HH-responsive Daoy cells with CK1D008 and for comparison with the known CSNK1D inhibitor SR-3029 [58]. As shown in Figure 3A, both CSNK1D inhibitors potently inhibited the activation of GLI1 mRNA expression in SAG-treated Daoy cells with $\mathrm{IC}_{50}$ values in the nanomolar range (Figure $3 \mathrm{~A}$ ). 
Likewise, both inhibitors decreased SAG-induced GLI1 protein levels in Daoy cells in a dose-dependent manner (Figure 3B). Neither the protein levels of CSNK1D nor those of GLI2 were affected by pharmacological inhibition of CSNK1D (Figure S3B). Consistent with the proliferative role of HH-GLI in Daoy cells, both CSNK1D inhibitors also reduced cell proliferation and viability in a dose-dependent manner (Figure S3C).

A

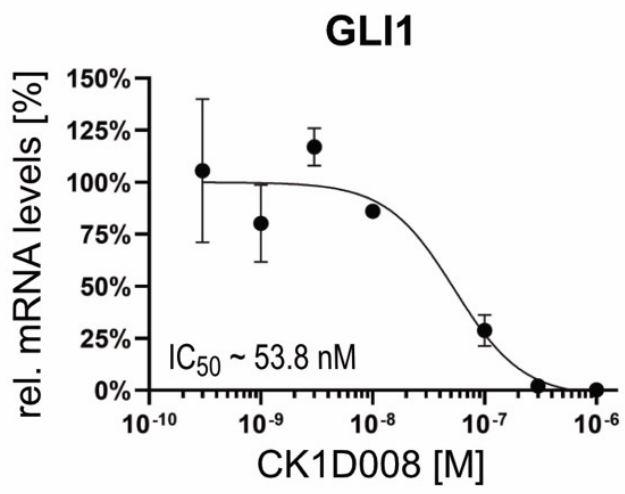

\section{Daoy + SAG}

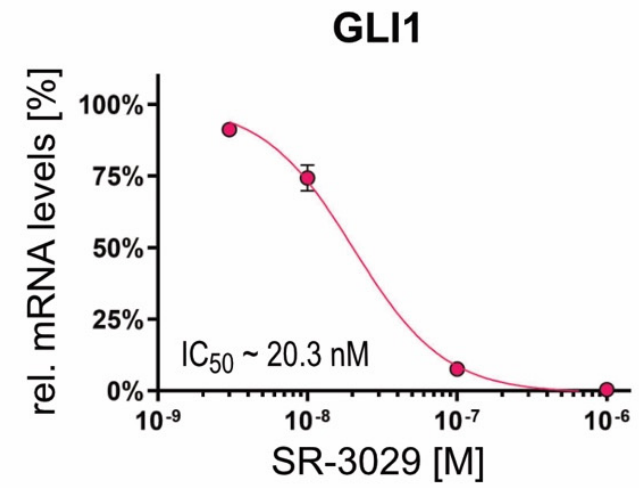

B

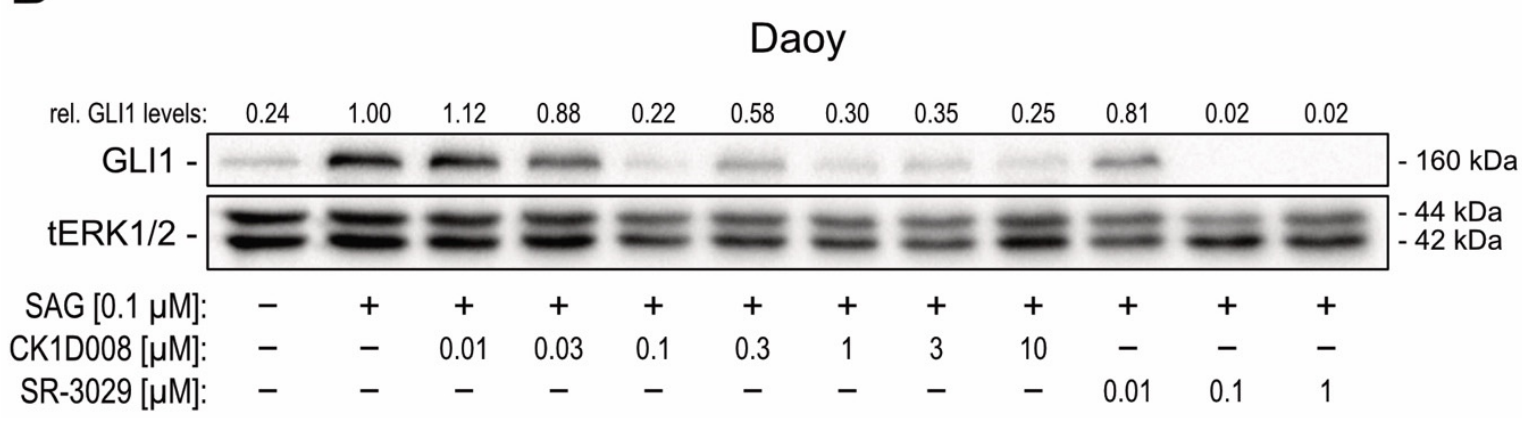

Figure 3. Pharmacological targeting of CSNK1D inhibits SMO-dependent GLI activation. (A) mRNA expression levels of GLI1 were analyzed by qPCR and expressed as percentage relative to the control sample $(n=3)$. (B) Representative Western blot analysis of GLI1 protein levels in Daoy cells treated with SAG [100 nM] and increasing concentrations of CK1D008 [0.01-10 $\mu \mathrm{M}]$ or SR-3029 [0.01-1 $\mu \mathrm{M}]$. Relative quantification of Western blot bands was conducted via densitometric image analysis using Image Lab 5.0 software (Bio-Rad, Vienna, Austria). Relative protein levels normalized to the loading control tERK and to the SAG-treated sample are shown above each protein band.

Furthermore, to mimic SMOi resistance, we generated Daoy cells with an shRNAmediated knockdown of the GLI inhibitor SUFU [59], resulting in SMO-independent activation of GLI1 expression (Figure 4A,B). Of note, while vismodegib treatment failed to reduce GLI1 expression in Daoy-shSUFU cells, chemical targeting of CSNK1D with CK1D008 or SR-3029 efficiently reduced GLI1 protein expression and HH target gene expression in this SMO-independent model of GLI activation (Figure 4B and Figure S4A). To corroborate that CSNK1D inhibition is a potent strategy to block GLI activation in SMOi-resistant settings, we performed chemical inhibition of CSNK1D in A673 and MHHES-1 Ewing sarcoma cells both showing SMO-independent GLI1 expression. As shown in Figure 4C and Figure S4B, pharmacologic inhibition of CSNK1D with CK1D008 or SR-3029 efficiently reduced GLI1 expression in both cell lines. By contrast, vismodegib treatment did not affect GLI1 expression [60]. 


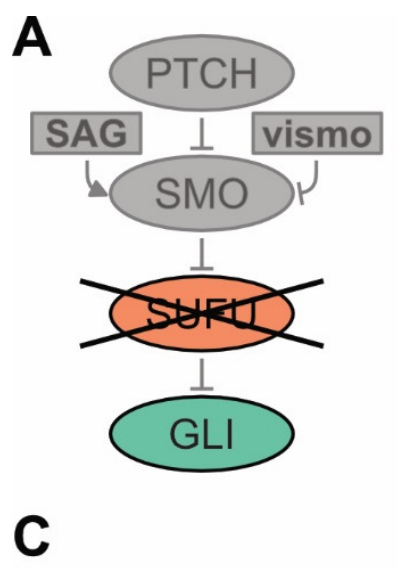

\section{B Daoy-shSUFU}
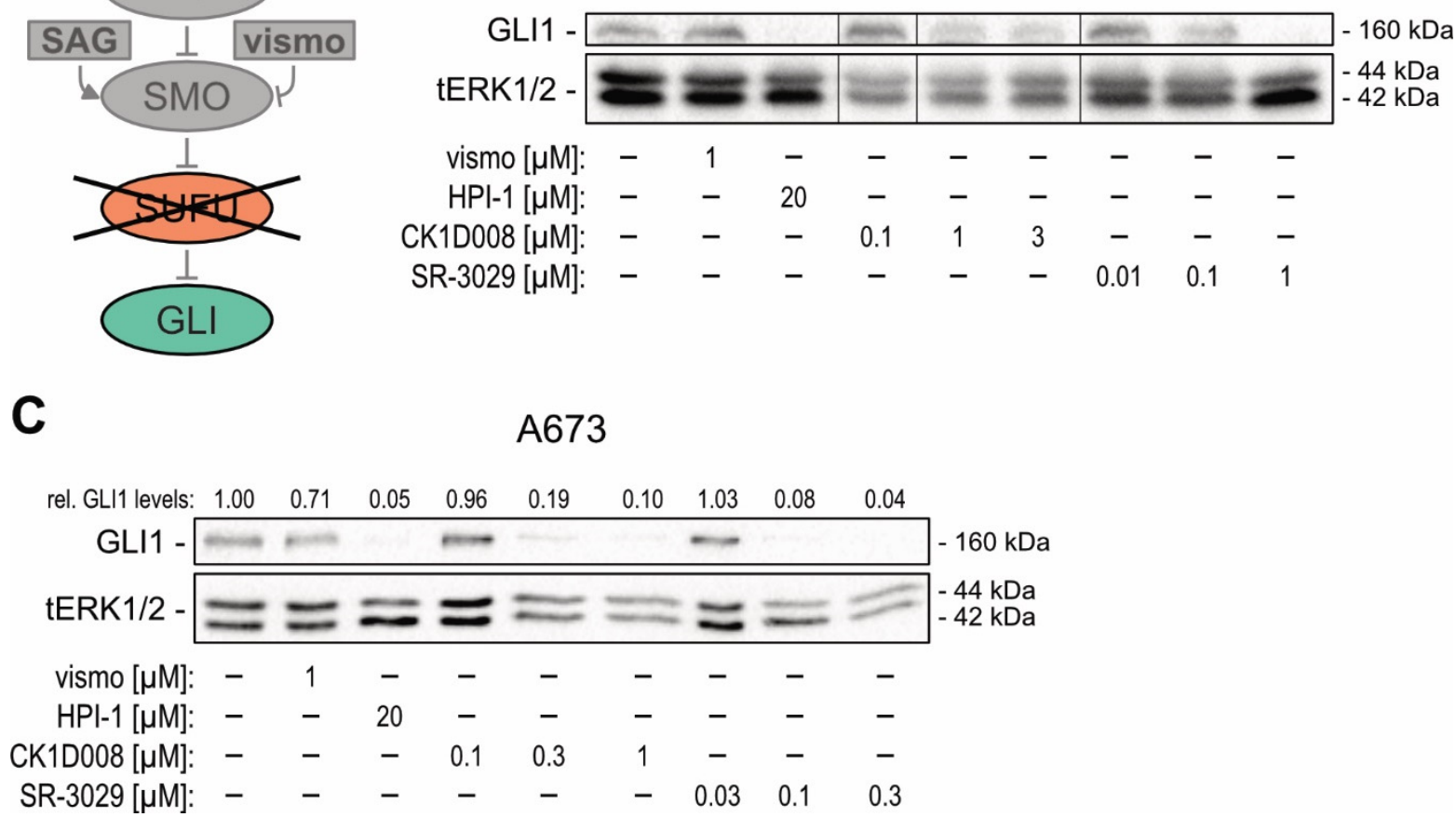

Figure 4. Pharmacological targeting of CSNK1D inhibits oncogenic HH-GLI signaling in SMOi-resistant cells. (A) Simplified schematic illustration of SMO-independent activation of HH-GLI signaling in Daoy medulloblastoma cells caused by the loss of the negative HH-GLI pathway regulator SUFU. (B) Representative Western blot analysis of GLI1 protein levels in Daoy-shSUFU cells treated with vismo $[1 \mu \mathrm{M}]$, HPI-1 [20 $\mu \mathrm{M}]$, CK1D008 [0.1-3 $\mu \mathrm{M}]$ or SR-3029 [0.01-1 $\mu$ M]. (C) Representative Western blot analysis of GLI1 in A673 cells treated with vismo [1 $\mu \mathrm{M}], \mathrm{HPI}-1$ [20 $\mu \mathrm{M}]$, CK1D008 [0.1-1 $\mu \mathrm{M}]$ or SR-3029 [0.03-0.3 $\mu \mathrm{M}]$. Relative quantification of Western blot bands was conducted via densitometric image analysis using Image Lab 5.0 software (Bio-Rad, Vienna, Austria). Relative protein levels normalized to the loading control tERK and to the Ctrl sample are shown above each protein band.

\subsection{Targeting the CSNK1D-GLI Axis Inhibits CSC-Like Characteristics In Vitro and In Vivo}

Clonogenic and self-renewing spheroid growth in 3-dimensional (3D) in vitro cultures and the initiation of in vivo tumor growth are considered characteristics of TIC [60]. To functionally addressed a putative role of the CSNK1D-GLI axis in TICs, we first performed genetic and pharmacologic targeting of CSNK1D and measured its impact on the 3D spheroid growth properties of GLI1-expressing A673 cells. Of note, shRNA-mediated knockdown of CSNK1D significantly diminished the clonogenic anchorage-independent growth capacity of A673 cells in 3D cultures (Figure 5A), while it did not affect anchoragedependent growth under 2D culture conditions (Figure S5A). Accordingly, pharmacological inhibition of CSNK1D with CK1D008 or SR-3029 both drastically reduced clonogenic spheroid growth in 3D cultures at concentrations that had no impact on cell growth under planar 2D conditions (Figure 5B and Figure S5B). In addition, the inhibitory effect of CK1D008 on clonal growth was also evaluated in HH-GLI-dependent pancreatic (PANC1), NSCLC (A549), glioma (LNT-229) and CRC (HT29, HCT15, HCT116) tumor cells [6,60-62]. To this end, tumor cells were pre-treated with inhibitor for $48 \mathrm{~h}$ and viable cells were seeded at limiting dilutions in an anchorage-dependent colony formation assay. CK1D008 efficiently reduced the colony formation ability of all tested cell lines at concentrations as low as $0.1-0.3 \mu \mathrm{M}$ (Figure S5C). 


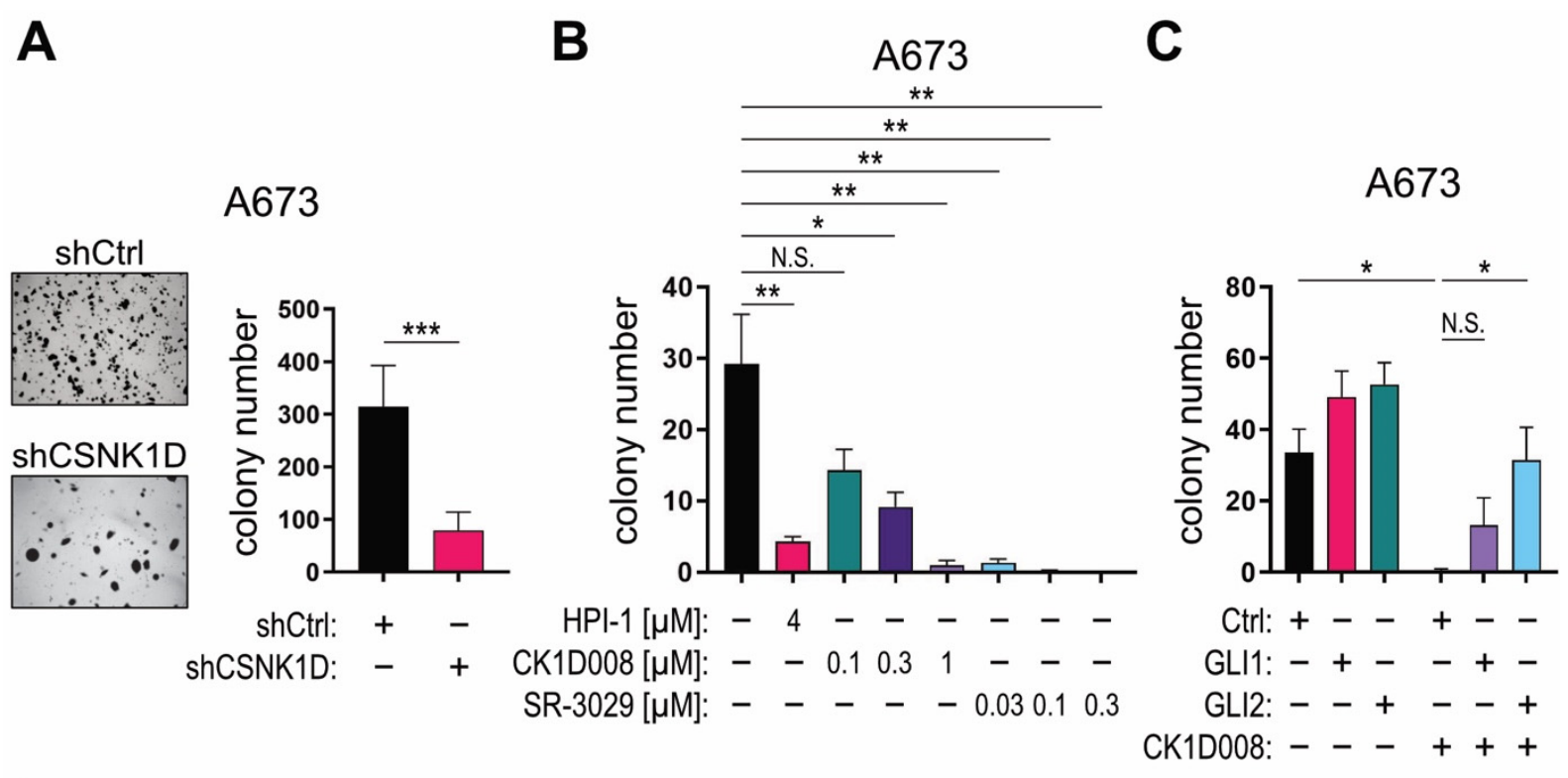

D
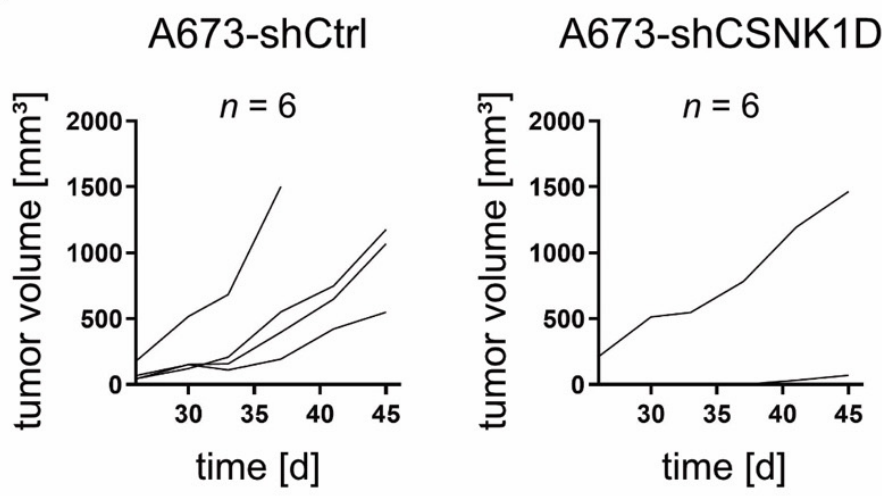

Figure 5. Targeting CSNK1D reduces GLI-dependent 3D tumor spheroid formation in vitro as well as tumor engraftment in vivo. (A) A673 cells were lentivirally transduced with shCSNK1D or control shRNA (shCtrl) and cultured under anchorage-independent conditions. Representative images of formed 3D spheroid colonies (left panel). The number of 3D spheroid colonies was counted (right panel) $(n=8)$. (B) A673 cells were cultured under anchorage-independent conditions and treated with the GLI inhibitor HPI-1 $[4 \mu \mathrm{M}]$, CK1D008 [0.1-1 $\mu \mathrm{M}]$ or SR-3029 [0.03-0.3 $\mu \mathrm{M}]$. The data represent the mean of six 3D culture experiments. (C) A673 cells were retrovirally transduced with GLI1, active GLI2 (GLI2act) or control overexpression constructs, cultured under anchorage-independent conditions and treated with CK1D008 at non-toxic concentration [0.3 $\mathrm{MM}$ ]. The number of 3D spheroid colonies was counted ( $n=4$ experiments). (D) A673 cells were lentivirally transduced with shCSNK1D or control shRNA (shCtrl) and engrafted in the flanks of NSG mice ( $n=6$ mice each). Tumor volume was measured every 3-4 days. Student's $t$ test was used for statistical analysis $\left({ }^{*} p<0.05 ;{ }^{* *} p<0.01\right.$; *** $p<0.001$ ).

GLI1 represents an important driver gene of proliferation and spheroid growth in Ewing sarcoma cells [29]. To further support that inhibition of CSNK1D decreases TIC properties via GLI1 inhibition, we performed a CRISPR/Cas-mediated GLI1 knockout in A673 cells (Figure S5D) and analyzed GLI1-deficient A673 cells for clonogenic spheroid growth in 3D and planar growth in 2D cultures. In line with our results on CSKN1D targeting, genetic deletion of GLI1 selectively abolished clonogenic spheroid formation in $3 \mathrm{D}$, while it did not affect the 2D growth properties (Figure S5E,F), suggesting that CSNK1D encodes a crucial positive regulator of oncogenic GLI1 in TIC.

To evaluate whether enforced overexpression of the GLI activator proteins GLI1 and GLI2 can attenuate the anti-tumor effect caused by CSNK1D inhibition, we overexpressed in A673 cells HA-tagged GLI1 and an active form of GLI2 [63], respectively (Figure S5G), and treated GLI1, GLI2, or empty-vector control cells with CK1D008. In line with GLI 
acting downstream of CSNK1D, GLI1 and GLI2 overexpression conferred at least partial resistance to CSNK1D inhibitor treatment compared to control cells (Figure 5C).

To investigate whether CSNK1D is required for GLI-driven tumor initiation in vivo, we performed xenograft experiments using GLI1-dependent A673 and GLI1-dependent PANC1 pancreatic cancer cells [60] with concomitant inhibition of CSNK1D. As shown in Figure 5D, CSNK1D knockdown in A673 cells severely impaired their engraftment ability compared to control cells transduced with non-targeting shRNA. Similarly, pretreatment of GLI1-dependent PANC1 cells with a low concentration of CK1D008 [0.3 $\mu \mathrm{M}]$ effectively abrogated the engraftment capacity of PANC1 cells (Figure $\mathrm{S} 5 \mathrm{H}$ ). These data strongly support a model where CSNK1D regulates the oncogenic activity of activator GLIs in TIC independent of SMO function.

\section{Discussion}

Hedgehog/GLI signaling has been associated with many human malignancies and aberrant pathway activation has been discovered in cancer stem cells with a critical role in tumor initiation, malignant growth, metastasis, and relapse [3,4,7,8,64]. Pharmacological targeting of oncogenic $\mathrm{HH}-\mathrm{GLI}$ is therefore considered a promising therapeutic strategy. Three SMO inhibitors, vismodegib, sonidegib and glasdegib, have been approved for the treatment of locally advanced and metastatic basal cell carcinoma and for acute myeloid leukemia, respectively [20,21,23,57]. Even though these inhibitors demonstrate remarkable therapeutic efficacy, treatment can cause frequent and severe side effects and result in acquired drug resistance. Additionally, several tumor entities are driven by SMO-independent GLI activity and thus display a priori SMOi resistance $[25,26,30,54]$. Since, the GLI transcription factors can integrate with other oncogenic signaling cascades and promote cancer progression and malignant properties of cancer (stem) cells [5,6,34,38-40,60,62,65], oncogenic GLI transcription factors represent attractive therapeutic targets for patients with acquired and a priori resistance to SMOi. Although some previous studies have shown that direct targeting of oncogenic GLI proteins is feasible and promising $[66,67]$, small molecule-mediated direct inhibition of transcription factors is generally considered to be very challenging. The identification of druggable key regulators of GLI activity such as readily targetable kinases promoting the oncogenic activity of GLI transcription factors is therefore a critical requirement and of high medical relevance and need.

In this study, we identify CSNK1D as a positive and druggable regulator of oncogenic GLI activity, both in canonical as well as SMO-independent settings of GLI activation. Furthermore, we describe the identification of the novel CSNK1D inhibitor CK1D008 and show that pharmacological targeting of CSNK1D with potent small molecule inhibitors including CK1D008 and SR-3029 [68] abolishes oncogenic HH-GLI signaling in distinct cancer entities with either SMO-dependent or SMO-independent oncogenic GLI activity. Of note, we provide evidence that the CSNK1D-GLI axis selectively promotes hallmarks of TICs including clonogenic growth in 2D- and 3D cultures and engraftment in immunocompromised mouse models, while not affecting the proliferation of non-TICs under standard 2D culture conditions. Therapeutic targeting of CSNK1D may therefore represent a promising approach to eradicate highly malignant GLI-driven TICs. Considering recent data on the immunosuppressive role of TICs/CSCs in several cancer entities [69] as well as the regulation of immunosuppressive factors by GLI [70-73] combination therapy with CSNK1D and immune checkpoint inhibitors is an attractive therapeutic strategy to be evaluated in follow-up pre-clinical studies.

CSNK1 family members interact with several oncogenic pathways such as the $\mathrm{HH}$, Hippo and WNT, and their aberrant regulation closely linked to several human malignancies [74]. Small molecule inhibitors of CSNK1 family members have been developed, such as the CSNK1D/E inhibitor SR-3029 which is a potent ATP-competitor with high specificity for CSNK1D and CSNK1E [68]. SR-3029 displays striking therapeutic efficacy in triple negative as well as HER $2^{+}$breast cancer models with WNT involvement [58]. Given 
the documented oncogenic role of HH-GLI in breast cancer development [75-77], it is possible that the therapeutic activity of this CSNK1 inhibitor also relies at least in part on the GLI inhibitory activity described in our study.

Mechanistically, we propose that CSNK1D positively regulates the stability of oncogenic GLI proteins. In this context it is noteworthy that Shi et al. have shown that members of the CSNK1 family phosphorylate GLI transcription factors at PKA-independent sites, thereby disrupting the interaction of GLI with SPOP. SPOP negatively regulates GLI activity by enhancing the proteasomal degradation of GLI proteins [50]. In line with these data, we observed that chemical inhibition of the proteasome machinery at least partially reversed the repressive effect of CSNK1D drugs on GLI protein expression levels (data not shown). Further biochemical and molecular studies will be required to precisely dissect the mechanism of action of CSNK1D on HH-GLI, and a careful evaluation and comparison of distinct and pharmacologically validated small-molecule inhibitors will finally reveal the therapeutic potential of CSNK1D targeting.

To address the oncogenic role of the CSNK1D-GLI axis in stem-like TICs, we performed 3D growth assays to monitor clonal spheroid growth, which is considered a hallmark of TICs [60]. Genetic inhibition of CSNK1D was sufficient to abrogate colony formation in Ewing sarcoma cells. Pharmacological targeting of CSNK1D by CK1D008 and SR-3029 selectively decreased colony formation at concentrations sufficient to abrogate $\mathrm{HH}$ pathway activity, while not affecting cell proliferation in planar 2D culture settings. This suggests that CSNK1D-GLI is preferentially required for the expansion of TIC rather than non-CSCs. In agreement with this notion, we show that genetic inhibition of CSNK1D diminishes the engraftment and tumor initiation capacity of GLI-dependent A673 Ewing sarcoma cells in immunodeficient mice. The tumor-initiating role of CSNK1D is further supported by our findings that pharmacological inhibition of CSNK1D abrogates the tumor initiation and in vivo engraftment capacity of GLI-dependent PANC1 cells [60].

In summary, we identified CSNK1D as a novel positive regulator of oncogenic GLI transcription factors in TIC. This study provides a basis for the development and use of selective CSNK1D inhibitors to abrogate HH-GLI signaling in SMOi-sensitive and SMOi-resistant settings, which is an important step towards the development of novel oncology drugs targeting GLI transcription factors to eliminate highly malignant cancer stem cells.

\section{Materials and Methods}

\subsection{Cell Lines and Reagents}

Daoy medulloblastoma cells (ATCC HTB-186), Ewing sarcoma cell lines A673 (ATCC CRL-1598) and MHH-ES-1 (DSMZ ACC 167) were used for chemical and genetic manipulation of CSNK1 and $\mathrm{HH}$ signaling pathway components. The following chemicals were used: Smoothened agonist SAG (Selleckchem, Houston, TX, USA), GDC-0449 (vismodegib; LC Laboratories, Woburn, MA, USA), HPI-1 (Sigma-Aldrich, St Louis, MO, USA), SR-3029 (Axon Medchem, Groningen, The Netherlands). For the analysis of HH-GLI activity, Daoy cells were kept confluent for at least $48 \mathrm{~h}$ and starved in $0.5 \%$ FBS (Sigma-Aldrich) overnight prior to stimulation with $100 \mathrm{nM}$ SAG. Chemicals or control solvents were added $2 \mathrm{~h}$ prior to SAG stimulation. Daoy cells were cultured in MEM (Sigma-Aldrich) supplemented with 10\% FBS (Sigma-Aldrich) and antibiotics (Penicillin-Streptomycin, Sigma-Aldrich). A673 cells were cultured in DMEM (Sigma-Aldrich) and MHH-ES-1 cells in RPMI-1640 (Sigma-Aldrich) supplemented with 10\% FBS and antibiotics and treated at confluency as indicated in the text. HEK293FT cells were cultured in DMEM supplemented with 10\% FBS, antibiotics, L-Glutamin (Sigma-Aldrich), and non-essential amino acids solution (Thermo Fisher Scientific, Waltham, MA, USA), and used for transfection experiments when they reached $\sim 80 \%$ confluency. 


\subsection{Identification and Characterization of CK1D008}

CK1D008 was selected from in-house library of $\sim 600$ small molecule kinase inhibitors (MW range 300-600 g/Mol) according to the following assay: A549 and PANC1 cells were seeded under proliferating (10\%) FBS and non-proliferating quiescent $(0.2 \%)$ FBS conditions, treated with screening compounds for $48 \mathrm{~h}$, and analyzed with crystal violet staining. Compounds potently reducing the cell numbers under $0.2 \%$ FBS (efficacy measure, cut-off of $0.3 \mu \mathrm{M}$ ) and a factor of 10 under proliferating conditions (selectivity factor, calculated as $\mathrm{IC}_{50}$ under proliferating $/ \mathrm{IC}_{50}$ under quiescent conditions) were selected for further analysis. CSNK1D kinase inhibition was measured at Reaction Biology according to their standard protocol using $20 \mu \mathrm{M}$ peptide substrate ([KRRRAL[pS]VASLPGL], $10 \mu \mathrm{M}$ ATP, and P33-labelling of the substrate as readout. Kinase selectivity was determined at $3 \mu \mathrm{M}$ by DiscoveRX KINOMEScan according to the manufacturer's protocol test. CK1D008 demonstrated an excellent selectivity with S (10) of 0.01 ( 5 out of 403 tested kinases inhibited by $>90 \%$, all closely related).

\subsection{Cell Proliferation and Anchorage-Dependent and -Independent Growth Assays}

Cell proliferation and viability were determined by the AlamarBlue ${ }^{\mathrm{TM}}$ assay. Cells were seeded in 96-well plates at an appropriate density depending on their growth properties to ensure that confluency would not be reached during the experiment. Cell viability was determined at indicated time points by adding 1/10 volume AlamarBlue solution (Biorad, Hercules, CA, USA) to each well, followed by measuring fluorescence with an excitation of $560 \mathrm{~nm}$ and an emission of $590 \mathrm{~nm}$, or absorbance at $570 \mathrm{~nm}$ and $600 \mathrm{~nm}$. The percentage of viable cells was normalized to the number of viable cells in the respective control.

For anchorage-independent three-dimensional (3D) spheroid colony growth cultures, $1 \times 10^{4}$ cells were seeded in a 12-well plate, as described in [65].

For anchorage-dependent limited dilution colony formation assay, tumor cells were pre-treated with compounds for $48 \mathrm{~h}$ at $0.2 \%$ FBS. Next, 200 viable cells per well were seeded into 6-well plates and incubated without compound for 9-11 days followed by crystal violet staining and colony counting. To evaluate the potential irreversible toxic effect of compound pre-treatment, cells were incubated without compound for another $24 \mathrm{~h}$ and analyzed for viability. Only compounds that were not toxic in this assay were considered as colony formation inhibitors.

\subsection{In Vivo Experiments}

For in vivo experiments, NOD-SCID IL2Rgamma ${ }^{-1-}$ (NSG) mice were kept in individually ventilated cages (IVC) under specific pathogen-free conditions (SPF). All animal experiments were performed in compliance with the national requirements and regulations. The A673 allograft assay was performed by injecting $1 \times 10^{6}$ A673 cells per $100 \mu \mathrm{L} 25 \%$ Matrigel (BD Biosciences, Franklin Lakes, NJ, USA) subcutaneously into the flanks of NSG mice. Tumor volume was measured every $3-4$ days with a caliper and calculated according to the formula $V=\frac{4 \pi}{3} \times \frac{\text { length }}{2} \times \frac{\text { width }}{2} \times \frac{\text { height }}{2}$. For PANC1 engraftment experiments, PANC1 cells were treated for $48 \mathrm{~h}$ prior to engraftment with DMSO or $0.3 \mu \mathrm{M}$ CK1D008 and analyzed for viability. Then, $1 \times 10^{6}$ viable PANC1 cells per mouse were inoculated into BalbC Nu/Nu athymic mice and monitored for tumor growth. Tumor growth was calculated according to the formula $V=\frac{\left(a \times b^{2}\right)}{2}$, where a and $\mathrm{b}$ correspond to the longest and shortest diameter of the engraftment. To control for the absence of irreversible toxic effects of compound pre-treatment at the time of harvest, pre-treated cells were further incubated under proliferating conditions for another $24 \mathrm{~h}$ without compound and re-analyzed for viability. Treatment with $0.3 \mu \mathrm{M}$ CK1D008 was not toxic to PANC1 cells at any timepoint and condition tested, yet highly efficient in preventing in vivo engraftment and tumor initiation of PANC1 cells. 


\subsection{RNA Isolation and Quantitative PCR ( $q P C R)$}

Total RNA was isolated using TRI reagent (Sigma-Aldrich) according to the manufacturer's protocol followed by $\mathrm{LiCl}$ precipitation. cDNA was synthesized with the M-MLV reverse transcriptase (Promega, Madsion, WI, USA) and qPCR was performed on the Rotor-Gene Q instrument (Qiagen, Hilden, Germany) using the GoTaq qPCR Mastermix (Promega). The qPCR temperature program is shown in Table S1. The qPCR primer with the following nucleotide sequences were used: RPLP0 fwd.: $5^{\prime}$-GGCACCATTGAAATCCTGAG TGATGTG-3' ${ }^{\prime}$, RPLP0 rv.: 5' -TTGCGGACACCCTCCAGGAAGC-3', GLI1 fwd.: 5'-TCTGGA CATACCCCACCTCCCTCTG-3', GLI1 rv:: 5'-ACTGCAGCTCCCCCAATTTTTCTGG-3', PTCH1 fwd.: 5'-TCCTCGTGTGCGCTGTCTTCCTTC-3', PTCH1 rv.: 5'-CGTCAGAAAGGC CAAAGCAACGTGA- $3^{\prime}$, HHIP fwd.: $5^{\prime}$-ACTTGCCGAGGCCATATTCCAGGTT- ${ }^{\prime}$, HHIP rv.: 5'-ATCCCCACTATGCAGGGCACCAAC-3', CSNK1D fwd.: $5^{\prime}$-TTTCTGCCGTTCCTTG CGTTTTGAC-3', CSNK1D rv:: 5'-GTGTGAGGTAGGGGTGAGGGGTGTG-3'.

\subsection{Western Blot Analysis}

After genomic modification or small molecule inhibitor treatment, cell samples were harvested and lyzed in Laemmli buffer [78], supplemented with phosphatase and protease inhibitors. Proteins were separated by SDS-PAGE and then blotted onto hybond ECL membranes (for original blots see Figure S6). Antibodies used are listed in Table S2.

\subsection{RNA Interference and Overexpression Constructs}

For RNA interference, two CSNK1D-targeting shRNA constructs were selected from the Mission TRC shRNA library (TRCN0000023769, named shCSNK1D\#1; TRCN0000361946, named shCSNK1D\#2; Sigma-Aldrich); and non-targeting scrambled shRNA served as control (shc002, named shCtrl, Sigma-Aldrich). SMOi-resistant Daoy cells with shRNAmediated knockdown of SUFU had been generated in our lab using the TRCN0000019466 construct (Sigma-Aldrich) [52].

For overexpression of GLI transcription factors, GLI1 and active GLI2 construct (GLI2act) [63] were HA-tagged and cloned into an empty pMSCV-puro vector using the Gibson assembly method. Retroviral transduction experiments were performed as described in [79]. Transduced cells were selected for puromycin resistance prior to further analysis.

\subsection{CRISPR-Mediated Knockout}

Lentiviral single guide (sg) RNA expression vector-targeting CSNK1D (\#GSGH11838246527777) and the corresponding non-targeting control (\#GSG11811) were purchased from Dharmacon (Horizon Discovery, Waterbeach, United Kingdom). For expression of the Cas 9 protein, the expression vector was used (Addgene plasmid \#59262; http:/ / n2t.net/addgene: 52962 (accessed on 1 December 2017), RRID:Addgene_52962) [80]. Cells were first transduced with the lentiCas9-Blast vector, selected for blasticidin resistance, and, afterwards, were lentivirally transduced with the CSNK1D-targeting sgRNA construct conferring puromycin resistance. Knockout efficacy was determined by target-locus sequencing of genomic DNA isolated using the DNA blood mini kit (Qiagen, Hilden, Germany). Knockout efficacy was calculated using TIDE (https: / tide.deskgen.com (accessed on 1 December 2017)) [81].

A GLI1 sgRNA-targeting sequence was designed using GPP sgRNA designer (https: / / portals.broadinstitute.org/gpp/public/analysis-tools/sgrna-design (accessed on 1 December 2017)), and a sgRNA-targeting eGFP was used as control. The following sgRNA nucleotide sequences were used for CRISPR-mediated knockout: GLI1: 5'-AACTCGCGATGC ACATCTCC-3' ${ }^{\prime}$, non-targeting control: 5'-GAGCTGGACGGCGACGTAAA-3'. sgRNA oligos were cloned into the lentiCRISPRv2 vector (Addgene plasmid \#52961; http:/ / n2 t.net/addgene:52961 (accessed on 1 December 2017); RRID:Addgene_52961) [80]. Cells were transduced with either the GLI1-targeting or the control construct, which were then selected for puromycin resistance, as described in [79]. GLI1 knockout efficacy was calcu- 
lated using TIDE (https:/ / tide.deskgen.com (accessed on 1 December 2017)) [81]. To isolate GLI1 knockout cells, sgGLI1-transduced cells were seeded at a low density in a 96-well plate and cultured in A673-conditioned media cleared by filtration through $0.45-\mu \mathrm{m}$ filters. Clonal colonies were expanded for further experiments.

\subsection{Statistical Analysis}

Statistical analysis and graph design were carried out using GraphPad Prism 8 software (GraphPad Software, San Diego, CA, USA). Data on bar charts and curves are depicted as mean values with the standard deviation indicated by error bars.

\section{Conclusions}

In this study, we identified CSNK1D as a critical positive regulator of oncogenic GLI activity and demonstrated that targeting CSNK1D interferes with the malignant properties of GLI-dependent TIC. Of note, genetic as well as pharmacologic inhibition of CSNK1D efficiently represses oncogenic GLI activity in cancer cells resistant to FDA-approved $\mathrm{HH}$ pathway inhibitors targeting the essential $\mathrm{HH}$ effector SMO. Targeting CSNK1D with compounds such as SR-3029 and CK1D008 may, therefore, be a promising future strategy to treat cancer patients with acquired or a priori resistance to SMOi, and to hopefully reduce severe side effects known to be caused by established anti-SMO drugs.

Supplementary Materials: The following are available online at https:/ /www.mdpi.com/article/10 $.3390 /$ cancers13164227/s1, Figure S1: S1 Targeting CSNK1D does not interfere with ciliogenesis in Daoy cells, Figure S2: Targeting CSNK1D interferes with oncogenic HH-GLI signaling in SMOiresistant Ewing sarcoma cells, Figure S3: Effects of pharmacological targeting of CSNK1D on the proliferation of A549 and Daoy cells, Figure S4: Targeting of CSNK1D reduces HH target gene expression in SMOi-resistant cell lines, Figure S5: Pharmacologic and genetic inhibition of CSNK1D selectively abrogates clonal growth and impairs in vivo engraftment of GLI-dependent PANC-1 cancer cells, Figure S6: Original Western Blot, Table S1: qPCR cycling program, Table S2: Western Blot antibodies.

Author Contributions: Conceptualization, E.P., W.G., S.H. and F.A.; data validation, formal analysis, investigation, E.P., W.G., T.P. and S.K.A.; methods and resources, A.R., S.G.-G. and F.R.; medicinal chemistry, conceptualization, compound screening and biological evaluation of CK1D008, M.Z., S.M. and S.H.; data curation, E.P., T.P., S.K.A. and F.V.; manuscript writing E.P., D.P.E., S.G.-G., S.H. and F.A.; visualization, E.P., D.P.E. and S.K.A.; supervision, project administration and funding acquisition F.A. All authors have read and agreed to the published version of the manuscript.

Funding: This research was funded by the Cancer Cluster Salzburg (project 20102-P1601064-FPR012017), Open Access Funding by the Austrian Science Fund (FWF) (projects W1213, P25629), the Biomed Center Salzburg (project 20102-F1901165-KZP) and the priority program ACBN by the University of Salzburg.

Institutional Review Board Statement: Animal studies were approved by the institutional authorities and by the Federal Ministry of Science, Research and Economy (BMWFW-66.012/0016WF/V/3b/2015 and BMWFW-66.011/0030-II/3b/2014).

Informed Consent Statement: Not applicable.

Data Availability Statement: The data presented in this study are available on request from the corresponding author. The data are not publicly available due to patent and licensing reasons.

Acknowledgments: The authors thank Sabine Siller and Philip Markus Wolf for their excellent technical support. The graphical abstract has been designed with Biorender.com (accessed on 31 October 2020). We dedicate this publication to our dear colleague Mirko Zaja, who sadly passed away during this study.

Conflicts of Interest: M.Z., S.M. and S.H. are employees of 4SC AG. The other authors declare no conflict of interest. 


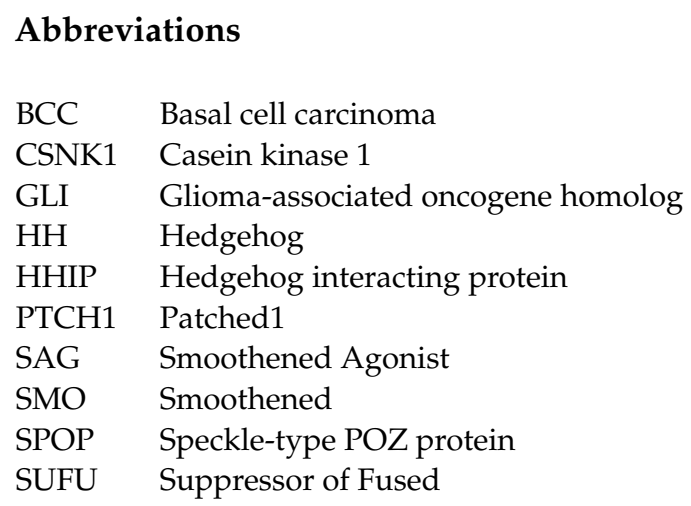

\section{References}

1. Bajaj, J.; Diaz, E.; Reya, T. Stem cells in cancer initiation and progression. J. Cell Biol. 2020, 219, e201911053. [CrossRef] [PubMed]

2. Valent, P.; Bonnet, D.; De Maria, R.; Lapidot, T.; Copland, M.; Melo, J.V.; Chomienne, C.; Ishikawa, F.; Schuringa, J.J.; Stassi, G.; et al. Cancer stem cell definitions and terminology: The devil is in the details. Nat. Rev. Cancer 2012, 12, 767-775. [CrossRef]

3. Ruiz i Altaba, A.; Mas, C.; Stecca, B. The Gli code: An information nexus regulating cell fate, stemness and cancer. Trends Cell Biol. 2007, 17, 438-447. [CrossRef]

4. Stecca, B.; Ruiz i Altaba, A. Context-dependent regulation of the GLI code in cancer by HEDGEHOG and non-HEDGEHOG signals. J. Mol. Cell. Biol. 2010, 2, 84-95. [CrossRef]

5. Zbinden, M.; Duquet, A.; Lorente-Trigos, A.; Ngwabyt, S.N.; Borges, I.; Ruiz i Altaba, A. NANOG regulates glioma stem cells and is essential in vivo acting in a cross-functional network with GLI1 and p53. EMBO J. 2010, 29, 2659-2674. [CrossRef] [PubMed]

6. Varnat, F.; Duquet, A.; Malerba, M.; Zbinden, M.; Mas, C.; Gervaz, P.; Ruiz i Altaba, A. Human colon cancer epithelial cells harbour active HEDGEHOG-GLI signalling that is essential for tumour growth, recurrence, metastasis and stem cell survival and expansion. EMBO Mol. Med. 2009, 1, 338-351. [CrossRef]

7. Aberger, F.; Ruiz i Altaba, A. Context-dependent signal integration by the GLI code: The oncogenic load, pathways, modifiers and implications for cancer therapy. Semin. Cell Dev. Biol. 2014, 33, 93-104. [CrossRef]

8. Teglund, S.; Toftgard, R. Hedgehog beyond medulloblastoma and basal cell carcinoma. Biochim. Biophys. Acta 2010, 1805, 181-208. [CrossRef]

9. Hui, C.C.; Angers, S. Gli proteins in development and disease. Annu. Rev. Cell Dev. Biol. 2011, 27, 513-537. [CrossRef] [PubMed]

10. Jiang, J.; Hui, C.C. Hedgehog signaling in development and cancer. Dev. Cell 2008, 15, 801-812. [CrossRef] [PubMed]

11. Nieuwenhuis, E.; Hui, C.C. Hedgehog signaling and congenital malformations. Clin. Genet. 2005, 67, 193-208. [CrossRef]

12. Rohatgi, R.; Milenkovic, L.; Scott, M.P. Patched1 regulates hedgehog signaling at the primary cilium. Science 2007, 317, 372-376. [CrossRef]

13. Kasper, M.; Regl, G.; Frischauf, A.M.; Aberger, F. GLI transcription factors: Mediators of oncogenic Hedgehog signalling. Eur. J. Cancer 2006, 42, 437-445. [CrossRef] [PubMed]

14. Briscoe, J.; Therond, P. Hedgehog signaling: From the Drosophila cuticle to anti-cancer drugs. Dev. Cell 2005, 8, 143-151. [CrossRef] [PubMed]

15. Hooper, J.E.; Scott, M.P. Communicating with Hedgehogs. Nat. Rev. Mol. Cell Biol. 2005, 6, 306-317. [CrossRef]

16. Goetz, S.C.; Anderson, K.V. The primary cilium: A signalling centre during vertebrate development. Nat Rev Genet. 2010, 11, 331-344. [CrossRef]

17. He, M.; Agbu, S.; Anderson, K.V. Microtubule motors drive hedgehog signaling in primary cilia. Trends Cell Biol. 2017, 27, 110-125. [CrossRef]

18. Atwood, S.X.; Whitson, R.J.; Oro, A.E. Advanced treatment for basal cell carcinomas. Cold Spring Harb. Perspect. Med. 2014, 4, a013581. [CrossRef] [PubMed]

19. Tang, J.Y.; Ally, M.S.; Chanana, A.M.; Mackay-Wiggan, J.M.; Aszterbaum, M.; Lindgren, J.A.; Ulerio, G.; Rezaee, M.R.; Gildengorin, G.; Marji, J.; et al. Inhibition of the hedgehog pathway in patients with basal-cell nevus syndrome: Final results from the multicentre, randomised, double-blind, placebo-controlled, phase 2 trial. Lancet Oncol. 2016, 17, 1720-1731. [CrossRef]

20. Von Hoff, D.D.; LoRusso, P.M.; Rudin, C.M.; Reddy, J.C.; Yauch, R.L.; Tibes, R.; Weiss, G.J.; Borad, M.J.; Hann, C.L.; Brahmer, J.R.; et al. Inhibition of the hedgehog pathway in advanced basal-cell carcinoma. N. Engl. J. Med. 2009, 361, 1164-1172. [CrossRef]

21. Migden, M.R.; Guminski, A.; Gutzmer, R.; Dirix, L.; Lewis, K.D.; Combemale, P.; Herd, R.M.; Kudchadkar, R.; Trefzer, U.; Gogov, S.; et al. Treatment with two different doses of sonidegib in patients with locally advanced or metastatic basal cell carcinoma (BOLT): A multicentre, randomised, double-blind phase 2 trial. Lancet Oncol. 2015, 16, 716-728. [CrossRef]

22. Sekulic, A.; Migden, M.R.; Oro, A.E.; Dirix, L.; Lewis, K.D.; Hainsworth, J.D.; Solomon, J.A.; Yoo, S.; Arron, S.T.; Friedlander, P.A.; et al. Efficacy and safety of vismodegib in advanced basal-cell carcinoma. N. Engl. J. Med. 2012, 366, 2171-2179. [CrossRef]

23. Norsworthy, K.J.; By, K.; Subramaniam, S.; Zhuang, L.; Del Valle, P.L.; Przepiorka, D.; Shen, Y.L.; Sheth, C.M.; Liu, C.; Leong, R.; et al. FDA approval summary: Glasdegib for newly diagnosed acute myeloid leukemia. Clin. Cancer Res. 2019, 25, 6021-6025. [CrossRef] 
24. Tang, J.Y.; Mackay-Wiggan, J.M.; Aszterbaum, M.; Yauch, R.L.; Lindgren, J.; Chang, K.; Coppola, C.; Chanana, A.M.; Marji, J.; Bickers, D.R.; et al. Inhibiting the hedgehog pathway in patients with the basal-cell nevus syndrome. N. Engl. J. Med. 2012, 366, 2180-2188. [CrossRef] [PubMed]

25. Atwood, S.X.; Sarin, K.Y.; Whitson, R.J.; Li, J.R.; Kim, G.; Rezaee, M.; Ally, M.S.; Kim, J.; Yao, C.; Chang, A.L.; et al. Smoothened variants explain the majority of drug resistance in basal cell carcinoma. Cancer Cell 2015, 27, 342-353. [CrossRef]

26. Sharpe, H.J.; Pau, G.; Dijkgraaf, G.J.; Basset-Seguin, N.; Modrusan, Z.; Januario, T.; Tsui, V.; Durham, A.B.; Dlugosz, A.A.; Haverty, P.M.; et al. Genomic analysis of smoothened inhibitor resistance in basal cell carcinoma. Cancer Cell 2015, 27, 327-341. [CrossRef]

27. Yauch, R.L.; Dijkgraaf, G.J.; Alicke, B.; Januario, T.; Ahn, C.P.; Holcomb, T.; Pujara, K.; Stinson, J.; Callahan, C.A.; Tang, T.; et al. Smoothened mutation confers resistance to a Hedgehog pathway inhibitor in medulloblastoma. Science 2009, 326, 572-574. [CrossRef] [PubMed]

28. Buonamici, S.; Williams, J.; Morrissey, M.; Wang, A.; Guo, R.; Vattay, A.; Hsiao, K.; Yuan, J.; Green, J.; Ospina, B.; et al. Interfering with resistance to smoothened antagonists by inhibition of the PI3K pathway in medulloblastoma. Sci. Transl. Med. 2010, 2, 51ra70. [CrossRef]

29. Bonilla, X.; Parmentier, L.; King, B.; Bezrukov, F.; Kaya, G.; Zoete, V.; Seplyarskiy, V.B.; Sharpe, H.J.; McKee, T.; Letourneau, A.; et al. Genomic analysis identifies new drivers and progression pathways in skin basal cell carcinoma. Nat. Genet. 2016, 48, 398-406. [CrossRef]

30. Atwood, S.X.; Li, M.; Lee, A.; Tang, J.Y.; Oro, A.E. GLI activation by atypical protein kinase C iota/lambda regulates the growth of basal cell carcinomas. Nature 2013, 494, 484-488. [CrossRef]

31. Whitson, R.J.; Lee, A.; Urman, N.M.; Mirza, A.; Yao, C.Y.; Brown, A.S.; Li, J.R.; Shankar, G.; Fry, M.A.; Atwood, S.X.; et al. Noncanonical hedgehog pathway activation through SRF-MKL1 promotes drug resistance in basal cell carcinomas. Nat. Med. 2018, 24, 271-281. [CrossRef]

32. Zhao, X.; Ponomaryov, T.; Ornell, K.J.; Zhou, P.; Dabral, S.K.; Pak, E.; Li, W.; Atwood, S.X.; Whitson, R.J.; Chang, A.L.; et al. RAS/MAPK activation drives resistance to smo inhibition, metastasis, and tumor evolution in shh pathway-dependent tumors. Cancer Res. 2015, 75, 3623-3635. [CrossRef]

33. Kuonen, F.; Huskey, N.E.; Shankar, G.; Jaju, P.; Whitson, R.J.; Rieger, K.E.; Atwood, S.X.; Sarin, K.Y.; Oro, A.E. Loss of primary cilia drives switching from hedgehog to Ras/MAPK pathway in resistant basal cell carcinoma. J. Investig. Dermatol. 2019, 139, 1439-1448. [CrossRef]

34. Brewster, R.; Mullor, J.L.; Ruiz i Altaba, A. Gli2 functions in FGF signaling during antero-posterior patterning. Development 2000, 127, 4395-4405. [CrossRef]

35. Gruber, W.; Hutzinger, M.; Elmer, D.P.; Parigger, T.; Sternberg, C.; Cegielkowski, L.; Zaja, M.; Leban, J.; Michel, S.; Hamm, S.; et al. DYRK1B as therapeutic target in Hedgehog/GLI-dependent cancer cells with Smoothened inhibitor resistance. Oncotarget 2016, 7, 7134-7148. [CrossRef]

36. Kasper, M.; Schnidar, H.; Neill, G.W.; Hanneder, M.; Klingler, S.; Blaas, L.; Schmid, C.; Hauser-Kronberger, C.; Regl, G.; Philpott, M.P.; et al. Selective modulation of Hedgehog/GLI target gene expression by epidermal growth factor signaling in human keratinocytes. Mol. Cell. Biol. 2006, 26, 6283-6298. [CrossRef] [PubMed]

37. Lauth, M.; Bergstrom, A.; Shimokawa, T.; Tostar, U.; Jin, Q.; Fendrich, V.; Guerra, C.; Barbacid, M.; Toftgard, R. DYRK1Bdependent autocrine-to-paracrine shift of Hedgehog signaling by mutant RAS. Nat. Struct. Mol. Biol. 2010, 17, 718-725. [CrossRef] [PubMed]

38. Neill, G.W.; Harrison, W.J.; Ikram, M.S.; Williams, T.D.; Bianchi, L.S.; Nadendla, S.K.; Green, J.L.; Ghali, L.; Frischauf, A.M.; O'Toole, E.A.; et al. GLI1 repression of ERK activity correlates with colony formation and impaired migration in human epidermal keratinocytes. Carcinogenesis 2008, 29, 738-746. [CrossRef]

39. Pelczar, P.; Zibat, A.; van Dop, W.A.; Heijmans, J.; Bleckmann, A.; Gruber, W.; Nitzki, F.; Uhmann, A.; Guijarro, M.V.; Hernando, E.; et al. Inactivation of Patched1 in mice leads to development of gastrointestinal stromal-like tumors that express Pdgfralpha but not kit. Gastroenterology 2013, 144, 134-144.e6. [CrossRef] [PubMed]

40. Sternberg, C.; Gruber, W.; Eberl, M.; Tesanovic, S.; Stadler, M.; Elmer, D.P.; Schlederer, M.; Grund, S.; Roos, S.; Wolff, F.; et al. Synergistic cross-talk of hedgehog and interleukin-6 signaling drives growth of basal cell carcinoma. Int. J. Cancer 2018, 143, 2943-2954. [CrossRef]

41. Varjosalo, M.; Bjorklund, M.; Cheng, F.; Syvanen, H.; Kivioja, T.; Kilpinen, S.; Sun, Z.; Kallioniemi, O.; Stunnenberg, H.G.; He, W.W.; et al. Application of active and kinase-deficient kinome collection for identification of kinases regulating hedgehog signaling. Cell 2008, 133, 537-548. [CrossRef] [PubMed]

42. Javelaud, D.; Pierrat, M.J.; Mauviel, A. Crosstalk between TGF-beta and hedgehog signaling in cancer. FEBS Lett. 2012, 586, 2016-2025. [CrossRef]

43. Yang, S.H.; Andl, T.; Grachtchouk, V.; Wang, A.; Liu, J.; Syu, L.J.; Ferris, J.; Wang, T.S.; Glick, A.B.; Millar, S.E.; et al. Pathological responses to oncogenic Hedgehog signaling in skin are dependent on canonical Wnt/beta3-catenin signaling. Nat. Genet. 2008, 40, 1130-1135. [CrossRef] [PubMed]

44. Jiang, J. CK1 in developmental signaling: Hedgehog and Wnt. Curr. Top. Dev. Biol. 2017, 123, 303-329. [CrossRef]

45. Price, M.A.; Kalderon, D. Proteolysis of the Hedgehog signaling effector Cubitus interruptus requires phosphorylation by Glycogen Synthase Kinase 3 and Casein Kinase 1. Cell 2002, 108, 823-835. [CrossRef] 
46. Price, M.A. CKI, there's more than one: Casein kinase I family members in Wnt and Hedgehog signaling. Genes Dev. 2006, 20, 399-410. [CrossRef]

47. Chen, Y.; Sasai, N.; Ma, G.; Yue, T.; Jia, J.; Briscoe, J.; Jiang, J. Sonic Hedgehog dependent phosphorylation by CK1alpha and GRK2 is required for ciliary accumulation and activation of smoothened. PLoS Biol. 2011, 9, e1001083. [CrossRef]

48. Purzner, T.; Purzner, J.; Buckstaff, T.; Cozza, G.; Gholamin, S.; Rusert, J.M.; Hartl, T.A.; Sanders, J.; Conley, N.; Ge, X.; et al. Developmental phosphoproteomics identifies the kinase CK2 as a driver of Hedgehog signaling and a therapeutic target in medulloblastoma. Sci. Signal 2018, 11, eaau5147. [CrossRef]

49. Jia, J.; Zhang, L.; Zhang, Q.; Tong, C.; Wang, B.; Hou, F.; Amanai, K.; Jiang, J. Phosphorylation by double-time/CKIepsilon and CKIalpha targets cubitus interruptus for Slimb/beta-TRCP-mediated proteolytic processing. Dev. Cell 2005, 9, 819-830. [CrossRef] [PubMed]

50. Shi, Q.; Li, S.; Li, S.; Jiang, A.; Chen, Y.; Jiang, J. Hedgehog-induced phosphorylation by CK1 sustains the activity of Ci/Gli activator. Proc. Natl. Acad. Sci. USA 2014, 111, E5651-E5660. [CrossRef] [PubMed]

51. Frank-Kamenetsky, M.; Zhang, X.M.; Bottega, S.; Guicherit, O.; Wichterle, H.; Dudek, H.; Bumcrot, D.; Wang, F.Y.; Jones, S.; Shulok, J.; et al. Small-molecule modulators of Hedgehog signaling: Identification and characterization of Smoothened agonists and antagonists. J. Biol. 2002, 1, 10. [CrossRef]

52. Gotschel, F.; Berg, D.; Gruber, W.; Bender, C.; Eberl, M.; Friedel, M.; Sonntag, J.; Rungeler, E.; Hache, H.; Wierling, C.; et al. Synergism between Hedgehog-GLI and EGFR signaling in Hedgehog-responsive human medulloblastoma cells induces downregulation of canonical Hedgehog-target genes and stabilized expression of GLI1. PLoS ONE 2013, 8, e65403. [CrossRef]

53. Eggenschwiler, J.T.; Anderson, K.V. Cilia and developmental signaling. Annu. Rev. Cell Dev. Biol. 2007, 23, 345-373. [CrossRef] [PubMed]

54. Beauchamp, E.; Bulut, G.; Abaan, O.; Chen, K.; Merchant, A.; Matsui, W.; Endo, Y.; Rubin, J.S.; Toretsky, J.; Uren, A. GLI1 is a direct transcriptional target of EWS-FLI1 oncoprotein. J. Biol. Chem. 2009, 284, 9074-9082. [CrossRef] [PubMed]

55. Beauchamp, E.M.; Ringer, L.; Bulut, G.; Sajwan, K.P.; Hall, M.D.; Lee, Y.C.; Peaceman, D.; Ozdemirli, M.; Rodriguez, O.; Macdonald, T.J.; et al. Arsenic trioxide inhibits human cancer cell growth and tumor development in mice by blocking Hedgehog/GLI pathway. J. Clin. Investig. 2011, 121, 148-160. [CrossRef] [PubMed]

56. Hyman, J.M.; Firestone, A.J.; Heine, V.M.; Zhao, Y.; Ocasio, C.A.; Han, K.; Sun, M.; Rack, P.G.; Sinha, S.; Wu, J.J.; et al. Smallmolecule inhibitors reveal multiple strategies for Hedgehog pathway blockade. Proc. Natl. Acad. Sci. USA 2009, 106, 14132-14137. [CrossRef]

57. Sekulic, A.; Von Hoff, D. Hedgehog pathway inhibition. Cell 2016, 164, 831. [CrossRef]

58. Rosenberg, L.H.; Lafitte, M.; Quereda, V.; Grant, W.; Chen, W.; Bibian, M.; Noguchi, Y.; Fallahi, M.; Yang, C.; Chang, J.C.; et al. Therapeutic targeting of casein kinase 1delta in breast cancer. Sci. Transl. Med. 2015, 7, 318ra202. [CrossRef] [PubMed]

59. Kogerman, P.; Grimm, T.; Kogerman, L.; Krause, D.; Unden, A.B.; Sandstedt, B.; Toftgard, R.; Zaphiropoulos, P.G. Mammalian suppressor-of-fused modulates nuclear-cytoplasmic shuttling of Gli-1. Nat. Cell Biol. 1999, 1, 312-319. [CrossRef] [PubMed]

60. Eberl, M.; Klingler, S.; Mangelberger, D.; Loipetzberger, A.; Damhofer, H.; Zoidl, K.; Schnidar, H.; Hache, H.; Bauer, H.C.; Solca, F.; et al. Hedgehog-EGFR cooperation response genes determine the oncogenic phenotype of basal cell carcinoma and tumour-initiating pancreatic cancer cells. EMBO Mol. Med. 2012, 4, 218-233. [CrossRef]

61. Rodriguez-Blanco, J.; Schilling, N.S.; Tokhunts, R.; Giambelli, C.; Long, J.; Liang Fei, D.; Singh, S.; Black, K.E.; Wang, Z.; Galimberti, F.; et al. The hedgehog processing pathway is required for NSCLC growth and survival. Oncogene 2013, 32, 2335-2345. [CrossRef] [PubMed]

62. Clement, V.; Sanchez, P.; de Tribolet, N.; Radovanovic, I.; Ruiz i Altaba, A. HEDGEHOG-GLI1 signaling regulates human glioma growth, cancer stem cell self-renewal, and tumorigenicity. Curr. Biol. 2007, 17, 165-172. [CrossRef]

63. Regl, G.; Neill, G.W.; Eichberger, T.; Kasper, M.; Ikram, M.S.; Koller, J.; Hintner, H.; Quinn, A.G.; Frischauf, A.M.; Aberger, F. Human GLI2 and GLI1 are part of a positive feedback mechanism in Basal Cell Carcinoma. Oncogene 2002, 21, 5529-5539. [CrossRef] [PubMed]

64. Peer, E.; Tesanovic, S.; Aberger, F. Next-generation hedgehog/GLI pathway inhibitors for cancer therapy. Cancers 2019, 11, 538. [CrossRef]

65. Schnidar, H.; Eberl, M.; Klingler, S.; Mangelberger, D.; Kasper, M.; Hauser-Kronberger, C.; Regl, G.; Kroismayr, R.; Moriggl, R.; Sibilia, M.; et al. Epidermal growth factor receptor signaling synergizes with Hedgehog/GLI in oncogenic transformation via activation of the MEK/ERK/JUN pathway. Cancer Res. 2009, 69, 1284-1292. [CrossRef] [PubMed]

66. Lauth, M.; Bergstrom, A.; Shimokawa, T.; Toftgard, R. Inhibition of GLI-mediated transcription and tumor cell growth by small-molecule antagonists. Proc. Natl. Acad. Sci. USA 2007, 104, 8455-8460. [CrossRef] [PubMed]

67. Infante, P.; Mori, M.; Alfonsi, R.; Ghirga, F.; Aiello, F.; Toscano, S.; Ingallina, C.; Siler, M.; Cucchi, D.; Po, A.; et al. Gli1/DNA interaction is a druggable target for Hedgehog-dependent tumors. EMBO J. 2015, 34, 200-217. [CrossRef]

68. Bibian, M.; Rahaim, R.J.; Choi, J.Y.; Noguchi, Y.; Schurer, S.; Chen, W.; Nakanishi, S.; Licht, K.; Rosenberg, L.H.; Li, L.; et al. Development of highly selective casein kinase 1delta/1epsilon (CK1delta/epsilon) inhibitors with potent antiproliferative properties. Bioorg. Med. Chem. Lett. 2013, 23, 4374-4380. [CrossRef]

69. Bayik, D.; Lathia, J.D. Cancer stem cell-immune cell crosstalk in tumour progression. Nat. Rev. Cancer 2021. [CrossRef] 
70. Grund-Groschke, S.; Ortner, D.; Szenes-Nagy, A.B.; Zaborsky, N.; Weiss, R.; Neureiter, D.; Wipplinger, M.; Risch, A.; Hammerl, P.; Greil, R.; et al. Epidermal activation of Hedgehog signaling establishes an immunosuppressive microenvironment in basal cell carcinoma by modulating skin immunity. Mol. Oncol. 2020, 14, 1930-1946. [CrossRef]

71. Grund-Groschke, S.; Stockmaier, G.; Aberger, F. Hedgehog/GLI signaling in tumor immunity-new therapeutic opportunities and clinical implications. Cell Commun Signal 2019, 17, 172. [CrossRef]

72. Chakrabarti, J.; Holokai, L.; Syu, L.; Steele, N.G.; Chang, J.; Wang, J.; Ahmed, S.; Dlugosz, A.; Zavros, Y. Hedgehog signaling induces PD-L1 expression and tumor cell proliferation in gastric cancer. Oncotarget 2018, 9, 37439-37457. [CrossRef] [PubMed]

73. Holokai, L.; Chakrabarti, J.; Broda, T.; Chang, J.; Hawkins, J.A.; Sundaram, N.; Wroblewski, L.E.; Peek, R.M., Jr.; Wang, J.; Helmrath, M.; et al. Increased Programmed death-ligand 1 is an early epithelial cell response to helicobacter pylori infection. PLoS Pathog. 2019, 15, e1007468. [CrossRef] [PubMed]

74. Schittek, B.; Sinnberg, T. Biological functions of casein kinase 1 isoforms and putative roles in tumorigenesis. Mol. Cancer 2014, 13, 231. [CrossRef]

75. Fiaschi, M.; Rozell, B.; Bergstrom, A.; Toftgard, R.; Kleman, M.I. Targeted expression of GLI1 in the mammary gland disrupts pregnancy-induced maturation and causes lactation failure. J. Biol. Chem. 2007, 282, 36090-36101. [CrossRef]

76. Fiaschi, M.; Rozell, B.; Bergstrom, A.; Toftgard, R. Development of mammary tumors by conditional expression of GLI1. Cancer Res. 2009, 69, 4810-4817. [CrossRef]

77. Norum, J.H.; Frings, O.; Kasper, M.; Bergholtz, H.; Zell Thime, H.; Bergstrom, A.; Andersson, A.; Kuiper, R.; Fredlund, E.; Sorlie, T.; et al. GLI1-induced mammary gland tumours are transplantable and maintain major molecular features. Int. J. Cancer 2020, 146, 1125-1138. [CrossRef]

78. Laemmli, U.K. Cleavage of structural proteins during the assembly of the head of bacteriophage T4. Nature 1970, 227, 680-685. [CrossRef]

79. Kasper, M.; Regl, G.; Eichberger, T.; Frischauf, A.M.; Aberger, F. Efficient manipulation of Hedgehog/GLI signaling using retroviral expression systems. Methods Mol. Biol. 2007, 397, 67-78. [CrossRef]

80. Sanjana, N.E.; Shalem, O.; Zhang, F. Improved vectors and genome-wide libraries for CRISPR screening. Nat. Methods 2014, 11, 783-784. [CrossRef] [PubMed]

81. Brinkman, E.K.; Chen, T.; Amendola, M.; van Steensel, B. Easy quantitative assessment of genome editing by sequence trace decomposition. Nucleic Acids Res. 2014, 42, e168. [CrossRef] [PubMed] 